\title{
PELATIHAN PENGGUNAAN MEDIA PEMBELAJARAN MANIPULATIF MATERI GEOMETRI PADA GURU SD NEGERI 2 SEBUBUS KECAMATAN PALOH
}

\author{
Marhadi Saputro ${ }^{1}$, Hartono ${ }^{2}$, Wandra Irvandi $^{3}$, Nurmaningsih ${ }^{4}$, \\ Dwi Oktaviana $^{5}$, Utin Desi Susiaty ${ }^{6}$, Yadi Ardiawan ${ }^{7}$ \\ 1,2,3,4,5,6,7 Program Studi Pendidikan Matematika, Fakultas Pendidikan MIPA dan Teknologi, \\ IKIP PGRI Pontianak, Jalan Ampera No.88 Pontianak \\ 1e-mail: marhadi.mat09@gmail.com
}

\begin{abstract}
Abstrak
Tujuan dari kegiatan pengabdian kepada masyarakat ini adalah untuk mengidentifikasi konsep-konsep matematika terutama geometri yang memerlukan media pembelajaran matematika inovatif untuk memudahkan siswa memahami materi serta meningkatkan pengetahuan guru tentang media pembelajaran matematika yang inovatif dan memiliki kemampuan untuk mengimplementasikannya dalam kegiatan pembelajaran di kelas. Kegiatan ini dilaksanakan di SD Negeri 2 Sebubus Kecamatan Paloh, Kabupaten Sambas dengan sasaran program pelatihan adalah guru matematika dari beberapa sekolah setempat baik tingkat SD, SMP dan SMA yang berjumlah 14 sekolah di Kecamatan Paloh. Langkah yang digunakan dalam pengabdian ini adalah perencanaan, tindakan, observasi, dan refleksi. Berdasarkan pelaksanaan kegiatan yang telah dilakukan diperoleh bahwa pelatihan ini sangat bermanfaat bagi guru-guru khususnya guru SD karena guru telah mengidentifikasi konsep matematika sesuai materi yang dibahas, meningkatkan pengetahuan guru tentang penggunaan media dalam pembelajaran yang akan berdampak positif terhadap hasil belajar siswa, motivasi belajar siswa, suasana pembelajaran yang menyenangkan, dan karakter menghargai ilmu matematika.
\end{abstract}

Kata kunci: media pembelajaran manipulatif, geometri

\begin{abstract}
The purpose of this community service activity is to identify mathematical concepts especially geometry that require innovative mathematics learning media to make it easier for students to understand the material and increase teacher knowledge about innovative mathematics learning media and have the ability to implement it in classroom learning activities. This activity was carried out at SDN 2 Sebubus in Kecamatan Paloh, Kabupaten Sambas. The target of the training program was mathematics teachers from several local schools, both elementary, junior and senior high schools, totaling 14 schools in Kecamatan Paloh. The steps used in this service are planning, action, observation, and reflection. Based on the implementation of the activities carried out it was found that this training was very beneficial for teachers especially elementary school teachers because the teacher had identified mathematical concepts according to the material discussed, increased teacher knowledge about the use of media in learning which would have a positive impact on student learning outcomes, student motivation, a pleasant learning atmosphere, and characters appreciate mathematics.
\end{abstract}

Keywords: manipulative learning media, geometry 


\section{PENDAHULUAN}

Media pembelajaran merupakan salah satu unsur penting dalam pembelajaran. Pembelajaran yang baik haruslah memiliki koneksi antara media, pengajar dan materi yang diajarkan. Tanpa ada salah satu dari ketiga hal tersebut, siswa sebagai objek pembelajaran tidak akan dapat menerima pengetahuan dari materi yang diajarkan. Dengan menggunakan media atau alat peraga tersebut anak akan lebih menghayati matematika secara nyata berdasarkan fakta yang jelas dan dapat dilihatnya. Sehingga anak lebih mudah memahami topik yang disajikan (Fadillah, Susiaty, \& Ardiawan, 2017). Selain itu, menurut (Herdianti \& Dharmayana, 2017) untuk menciptakan suasana pembelajaran yang kondusif dan menyenangkan guru dapat menggunakan media pembelajaran yang menarik.

Perkembangan ilmu pengetahuan dan teknologi semakin mendorong upayaupaya pembaharuan dalam pemanfaatan hasil-hasil teknologi dalam proses belajar mengajar. Para guru dituntut agar mampu menggunakan alat-alat yang dapat disediakan oleh sekolah, dan tidak tertutup kemungkinan bahwa alat-alat tersebut sesuai dengan perkembangan dan tuntutan zaman. Guru sekurang-kurangnya dapat menggunakan alat yang murah dan bersahaja tetapi merupakan keharusan dalam upaya mencapai tujuan pengajaran yang diharapkan.Disamping mampu menggunakan alat-alat yang tersedia, guru juga dituntut untuk dapat mengembangkan alat-alat yang tersedia, guru juga dituntut untuk dapat mengembangkan keterampilan membuat media pengajaran yang akan digunakannya apabila media tersebut belum tersedia.

Media Pembelajaran diartikan segala sesuatu yang dapat dipergunakan untuk merangsang pikiran, perasaan, perhatian dan kemampuan atau ketrampilan pebelajar sehingga dapat mendorong terjadinya proses belajar (Karyanti, 2019). Sedangkan menurut Briggs dalam (Karyanti, 2019) media pembelajaran adalah sarana fisik untuk menyampaikan isi/materi pembelajaran seperti: buku, film, video dan sebagainya. Kemudian menurut National Education Associaton dalam (Karyanti, 2019) mengungkapkan bahwa media pembelajaran adalah sarana komunikasi dalam bentuk cetak maupun pandang-dengar, termasuk teknologi perangkat keras. Pengertian media pembelajaran adalah segala alat pengajaran 
yang digunakan untuk untuk membantu menyampaikan materi pelajaran dalam proses belajar mengajar sehingga memudahkan pencapaian tujuan tujuan pembelajaran yang sudah dirumuskan.

Menurut (Mayasari, P, Novianti, Indriani, \& Noeruddin, 2017) selain sebagai media untuk membantu dalam menyampaikan materi pembelajaran, media pembelajaran yang dibuat secara menarik mampu menarik minat belajar peserta didik. Selain itu (Hartono, Haryadi, \& Susiaty, 2019) juga mengemukakan bahwa kehadiran media pembelajaran sangat membantu siswa yang sedang dalam fase operasional konkret dalam memahami materi yang bersifat abstrak atau kurang mampu dijelaskan dengan bahasa verbal. Menurut (Khairani \& Febrinal, 2016) media pembelajaran adalah faktor yang dapat membantu keberhasilan dalam proses pembelajaran di sekolah karena akan membantu guru dalam menyampaikan informasi kepada siswa ataupun sebaliknya (artinya media akan membantu guru dalam penyampaian materi). Melalui media, khususnya media yang jarang dijumpai, dapat menarik perhatian siswa dalam belajar. (Suprihatiningrum, 2013) mengemukakan bahwa media pembejalaran adalah alat dan bahan yang memuat dan membawa informasi atau bahan pelajaran agar tujuan pembelajaran bisa tercapai.

Media pembelajaran banyak sekali jenis dan macamnya. Mulai yang paling kecil sederhana dan murah hingga media yang canggih dan mahal harganya. Ada media yang dapat dibuat oleh guru sendiri, ada media yang diproduksi pabrik. Ada media yang sudah tersedia di lingkungan yang langsung dapat kita manfaatkan, ada pula media yang secara khusus sengaja dirancang untuk keperluan pembelajaran.

Meskipun media banyak ragamnya, namun kenyataannya tidak banyak jenis media yang biasa digunakan oleh guru di sekolah. Beberapa media yang paling akrab dan hampir semua sekolah memanfaatkan adalah media cetak (buku). Selain itu banyak juga sekolah yang telah memanfaatkan jenis media lain gambar, model, dan Overhead Projector (OHP) dan obyek-obyek nyata. Beberapa penyebab orang memilih media antara lain adalah: a) bermaksud mendemosntrasikannya seperti halnya pada kuliah tentang media; b) merasa sudah akrab dengan media 
tersebut; c) ingin memberi gambaran atau penjelasan yang lebih kongkrit; dan d) merasa bahwa media dapat berbuat lebih dari yang bisa dilakukannya. Jadi dasar pertimbangan untuk memilih media sangatlah sederhana, yaitu memenuhi kebutuhan atau mencapai tujuan yang diinginkan atau tidak. Media yang baik digunakan pada pembelajaran matematika sebaiknya media manipulatif yaitu media yang dapat dipegang, dibolak-balik, dipotong, maupun dilipat oleh peserta didik. Karena dengan menggunakan media manipulatif ini selain bisa membuat peserta didik aktif dalam pembelajaran media ini juga dapat membuat peserta didik menemukan masalah dan diharapkan dapat memecahkan masalahnya sendiri terhadap apa yang diamatinya (Herdianti \& Dharmayana, 2017). Menurut (Rosmalina, Darsono, \& Sulistiasih, 2019) salah satu media pembelajaran matematika yang dapat digunakan untuk membantu proses pembelajaran yaitu media manipulatif. Menurut (Yeni, 2011) media atau benda manipulatif adalah perangkat pembelajaran yang berupa benda fisik yang dapat dimanipulasi, memodelkan, dan memperagakan konsep serta proses matematika.

Geometri merupakan salah satu bidang dalam matematika yang mempelajari titik, garis, bidang dan ruang serta sifat-sifat, ukuran-ukuran, dan keterkaitan satu dengan yang lain. Bila dibandingkan dengan bidang-bidang lain dalam matematika, geometri merupakan salah satu bidang dalam matematika yang dianggap paling sulit untuk dipahami. Jiang dalam (Aden, 2011) menyatakan bahwa geometri merupakan salah satu bidang dalam matematika yang sangat lemah diserap oleh siswa sekolah. Selain itu materi ini membutuhkan kemampuan spasial yang baik. Siswa harus mengkonstruksi pemahamannya melalui visualisasi dari model geometri. Terkadang siswa mengalami kesulitan dalam membayangkan bentuk bangun datar atau bangun ruang yang dijelaskan oleh guru. Ditambah lagi guru Sekolah Dasar terkadang mencontohkan bangun ruang mengunakan ilustrasi pada bidang dua dimensi sehingga siswa bingung menginterpretasikan rumus yang sudah dipahami dengan gambar yang disajikan. Salah satu media pembelajaran yang dapat digunakan dalam pembelajaran geometri adalah benda-benda manipulatif. Benda manipulatif adalah perangkat pembelajaran yang berupa benda fisik yang dapat dimanipulasi, memodelkan dan 
memperagakan konsep serta proses matematika. Melalui benda-benda manipulatif tersebut diharapkan siswa dapat belajar sambil bermain sehingga siswa dapat secara aktif belajar dengan aktifitas yang menyenangkan (Yeni, 2011).

Penggunaan media dalam proses pembelajaran merupakan salah satu upaya untuk menciptakan pembelajaran yang lebih bermakna dan berkualitas. Menurut (Latuheru, 1988) penggunaan media dalam proses pembelajaran bertujuan agar proses pembelajaran dapat berlangsung secara tepat-guna dan berdaya guna sehingga mutu pendidikan dapat ditingkatkan. Media pembelajaran manipulatif berupa alat peraga berfungsi membantu proses internalisasi bentuk geometri secara utuh ke dalam pikiran siswa. Salah satu Sekolah Dasar yang siswanya mengalami kondisi tersebut adalah SD Negeri 2 Sebubus. Berdasarkan hasil wawancara bersama guru matematika di SD Negeri 2 Sebubus diperoleh informasi bahwa pembelajaran matematika di sekolah tersebut masih sangat membutuhkan variasi media alat peraga, demikian pula dengan beberapa sekolah lain di sekitar Sekolah tersebut.

Berdasarkan permasalahan guru matematika sebagai mitra kegiatan di atas, maka tim pengabdi berupaya memberikan solusi dengan memberikan pelatihan penggunaan media manipulatif materi geometri pada guru SD Negeri 2 Sebubus Kecamatan Paloh. Dengan dilaksanakannya kegiatan ini diharapkan guru matematika di sekolah mitra memperoleh pengetahuan, pengalaman dan menambah keterampilan dalam pembuatan dan penggunaan media dalam pembelajaran.

\section{METODE}

Metode pelaksanaan kegiatan PPM ini dilakukan dengan mengadopsi langkah-langkah action research yang terdiri dari 4 (empat) tahapan, yaitu: perencanaan tindakan, observasi dan evaluasi, dan refleksi, akan tetapi pelaksanaan tidak menggunakan konsep besiklus. Langkah-langkah kegiatan pelaksanaan adalah sebagai berikut: Perencanaan dengan kegiatan; (1) sosialisasi program PPM pada Sekolah Mitra; (2) Pertemuan tim pelaksana dan sekolah mitra; (3) Penyusunan program pelatihan. Tindakan dengan kegiatan (1) 
Menginformasikan atau mengenalkan pada guru tentang media pembelajaran matematika untuk memudahkan pemahaman siswa; (2) Mendemonstrasikan teknologi/ cara pembuatan media pembelajaran matematika; (3) Pelatihan cara penggunaan media pembelajaran matematika pada peserta dari guru-guru kelas SD Negeri 2 Sebubus; (4) Praktek penggunaan media pembelajaran di kelas pada sekolah mitra, dengan guru-guru lainnya sebagai pengamat. Observasi dilakukan terhadap proses pembelajaran dengan menggunakan media pembelajaran matematika oleh para guru mitra. Instrumen yang digunakan berupa catatan lapangan. Beberapa hal yang diobservasi adalah kendala-kendala dan kelemahankelemahan yang muncul dalam proses pembuatan media pembelajaran di lapangan maupun dalam proses penggunaan di kelas. Refleksi dengan kegiatan (1) mengevaluasi kendala-kendala dan kelemahan-kelemahan yang muncul dalam penggunaan media pembelajaran matematika pada penerapan pembelajaran di kelas; (2) hasil evaluasi akan digunakan untuk memperbaiki kekurangankekurangan yang ada dalam media pembelajaran.

Adapun lokasi kegiatan ini adalah di SD Negeri 2 Sebubus Kecamatan Paloh Kabupaten Sambas yang lokasinya seperti pada Gambar 1 berikut.

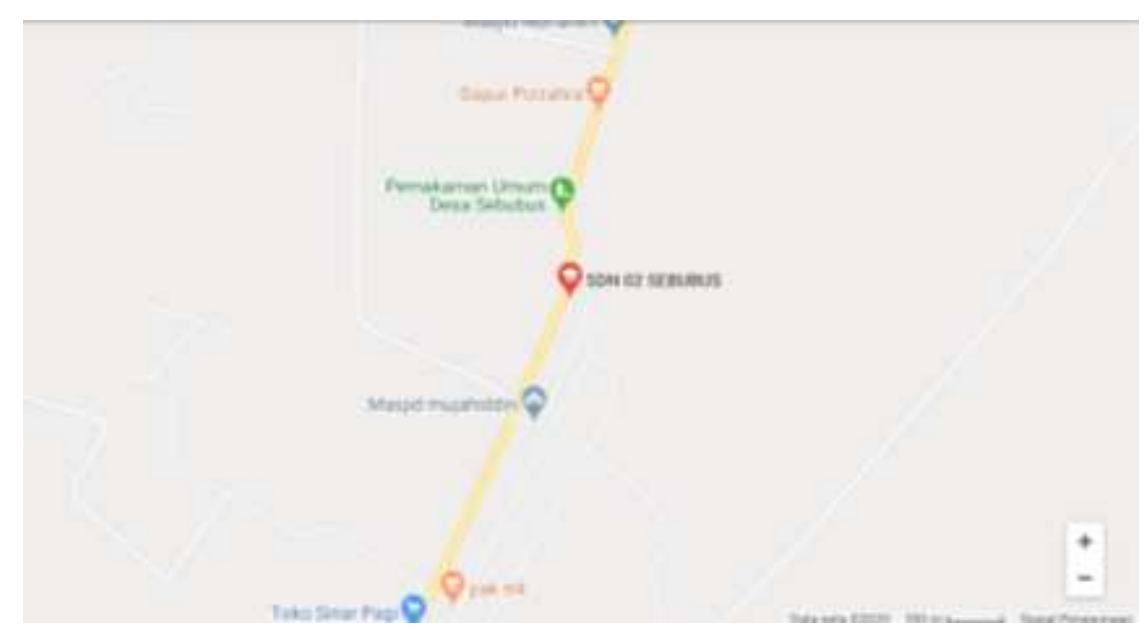

Gambar 1. Lokasi Kegiatan

\section{HASIL DAN PEMBAHASAN}

Kegiatan pengabdian dalam bentuk pelatihan penggunaan media pembelajaran manipulatif materi geometri pada guru SD Negeri 2 Sebubus Kecamatan Paloh Kabupaten Sambas ini dilaksanakan pada tanggal 25 Maret 
2019. Peserta dalam kegiatan ini berjumlah 17 orang guru matematika yang berasal dari beberapa SD/MI di kecamatan Paloh serta 2 sekolah tingkat menengah (SMP dan SMA) yang jaraknya berdekatan dengan SD Negeri 2 Sebubus.

Dalam kegiatan tersebut tim dosen IKIP PGRI Pontianak berjumlah 6 orang, 2 orang sebagai narasumber sedangkan yang lain sebagai pendamping guru dalam penggunaan media pembelajaran (alat peraga) manipulatif pada materi geometri. Selain dosen, tim pengabdian juga melibatkan 3 orang mahasiswa Pogram Studi Pendidikan Matematika sebagai moderator, dokumentasi dan administrasi.

Kegiatan ini diawali dengan pembukaan yang dibuka langsung oleh Kepala Sekolah SD Negeri 2 Sebubus, dan dihadiri setidaknya 6 SD/MI lain yang berada di Kecamatan Paloh. Hadir pula guru matematika SMP 7 dan SMA 1 Paloh yang berjarak tidak jauh dari SD Negeri 2 Sebubus. Acara selanjutnya adalah penyampaian materi tentang pembelajaran matematika yang menyenangkan serta penggunaan media dalam pembelajaran matematika.

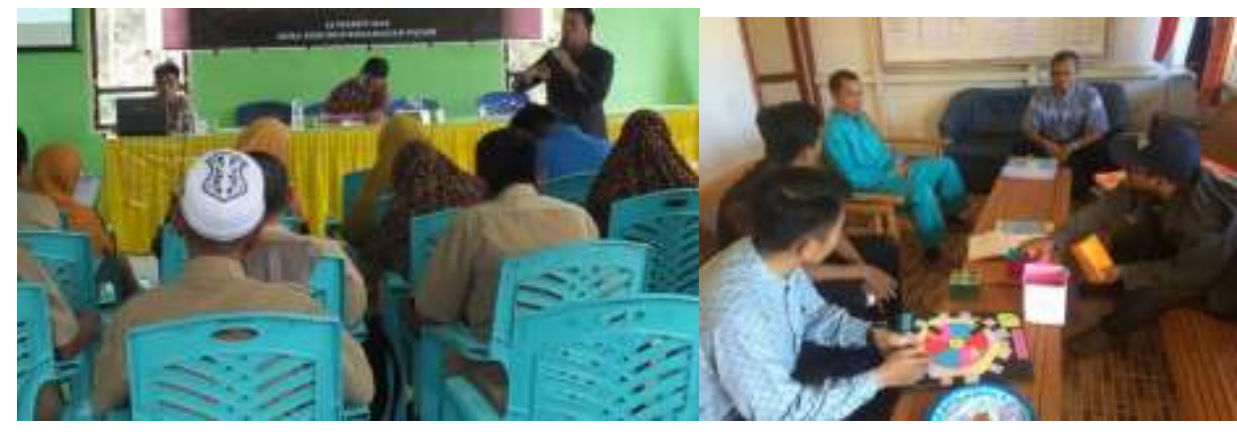

Gambar 2. Penyajian Materi Dan Demonstrasi Penggunaan Alat Peraga

Penyajian materi dalam kegiatan pengabdian pada masyarakat ini menggunakan kombinasi metode ceramah, tanya jawab, dan demonstrasi. Visualisasi kegiatan penyajian materi dalam kegiatan pengabdian pada masyarakat ini disajikan dalam Gambar 1. Tim pengabdian pada masayarakat dari dosen program studi Pendidikan Matematika IKIP PGRI Pontianak memulai penyajian materi dengan penjelasan tentang pembelajaran matematika yang efektif dan menyenangkan, ilustrasi pembuatan, dan demonstrasi cara menggunakannya di kelas. 
Untuk memperdalam pemahaman materi, peserta pelatihan diberi kesempatan untuk bertanya dan menyampaikan pendapat agar terjadi diskusi multiarah yang lebih mengefektifkan tercapainya tujuan kegiatan pengabdian pada masyarakat ini. Pada sesi ini, terjadi peningkatan pengetahuan dan pemahaman peserta tentang alat peraga matematika, cara pembuatan, dan cara penggunaannya. Diskusi yang terjadi cukup berkembang dengan baik, materi yang didiskusikan tidak hanya materi yang disampaikan, tetapi meluas materi lain yang terkait seperti pertanyaan peserta yang menanyakan tentang cara penggunaan alat peraga manipulatif pada materi lainnya.

Pada akhir kegiatan pengabdian pada masyarakat ini, peserta diminta mengisi angket untuk menilai kegiatan dan rencana tindak lanjut. Dalam pengisian angket, identitas pengisi angket tidak dicantumkan agar pengisi angket lebih nyaman dalam mengisi angket. Berdasarkan hasil isian angket diperoleh data mengenai pengisi angket, persepsi peserta terhadap kegiatan pengabdian ini, dan harapan peserta untuk kegiatan sejenis di masa datang. Hasil isian angket adalah sebagai berikut. (1) Peserta pelatihan sebanyak 17 orang guru, yang terdiri dari 11 orang guru matematika dari $6 \mathrm{SD}, 2$ orang guru matematika dari MI, 3 orang guru matematika SMP dan 1 orang guru matematika SMA. (2) Sebanyak 65\% peserta pernah menggunakan alat peraga manipulatif dalam pembelajaran matematika sebelumnya, namun frekuensinya tergolong jarang. (3) Seluruh peserta menyatakan dapat menerima materi dengan baik. (4) Seluruh peserta menyatakan bahwa kegiatan pengabdian pada masyarakat ini telah meningkatkan pengetahuan dan keterampilannya dalam meningkatkan kualitas pembelajaran di kelas. (5) Seluruh peserta menyatakan bahwa alat peraga manipulatif yang dibuat dalam kegiatan pengabdian ini dapat diimplemntasikan dalam pembelajaran sesungguhnya di SD terutama pada materi geometri dan akan berdampak positif terhadap hasil belajar siswa, motivasi belajar siswa, suasana pembelajaran yang menyenangkan, dan karakter menghargai ilmu matematika. (6) Sebanyak 95\% peserta pelatihan menyatakan bahwa implementasi alat peraga manipulatif dalam pembelajaran matematika dapat berpengaruh positif tehadap karakter siswa dalam menghargai guru dan siswa lainnya. 
Hasil yang diperoleh pada kegiatan pengabdian ini sejalan dengan beberapa pengabdian maupun penelitian yang terdahulu. Pengabdian yang dilakukan oleh (Mayasari et al., 2017) menyimpulkan bahwa dengan menggunakan media Geoboard pembelajaran matematika menjadi menyenangkan serta membuat siswa mudah dalam mengerjakan soal mencari luas bangun datar segi empat dan segitiga. Selanjutnya pengabdian yang dilakukan oleh (Yeni, 2011) mengemukakan bahwa pembelajaran matematika dengan memanfaatkan bendabenda manipulatif dapat menjadi alternatif model pembelajaran yang dapat diterapkan dalam upaya meningkatkan kualitas pendidikan. Penelitian yang dilakukan oleh (Susiaty \& Oktaviana, 2018) juga menyimpulkan bahwa media komputer berbasis Adobe Flash CS5 pada materi konsep segiempat dan seberapa jauh media ini dapat membantu pemahaman konsep segiempat. Penelitian yang dilakukan oleh (Rosmalina et al., 2019) menyimpulkan penggunaan media manipulatif memberikan pengaruh yang signifikan terhadap hasil belajar siswa. Selanjutnya penelitian yang dilakukan oleh (Kristanti, 2014) menyimpulkan hal yang sama yaitu siswa mencapai ketuntasan secara klasikal dengan bantuan media manipulatif papan berpaku.

\section{SIMPULAN}

Berdasarkan pelaksanaan kegiatan pengabdian kepada masyarakat dan hasil evaluasi terhadap pelaksaannya dapat disimpulkan bahwa: (1) kegiatan pelatihan ini sangat bermanfaat bagi guru-guru khususnya guru SD karena dengan menggunakan media dalam pembelajaran akan berdampak positif terhadap hasil belajar siswa, motivasi belajar siswa, suasana pembelajaran yang menyenangkan, dan karakter menghargai ilmu matematika; (2) kegiatan pelatihan serupa perlu diadakan kembali agar pengembangan pembelajaran dengan penggunaan media manipulatif lebih masif bagi guru di sekolah dan tidak terbatas pada materi geometri saja namun juga pada materi matematika lainnya. 


\section{DAFTAR PUSTAKA}

Aden, C. (2011). Meningkatkan Kemampuan penalaran dan komunikasi matematik melalui model think-pair-share berbantuan geometer's sketchpad,. Universitas Pendidikan Indonesia.

Fadillah, S., Susiaty, U. D., \& Ardiawan, Y. (2017). Pelatihan penggunaan media pembelajaran. GERVASI: Jurnal pengabdian kepada masyarakat, 3(1), 2.

Hartono, Haryadi, R., \& Susiaty, U. D. (2019). Pelatihan penggunaan media pembelajaran matematika pada MGMP matematika SMA kabupaten kubu raya. GERVASI: Jurnal pengabdian kepada masyarakat, 3(1), 2.

Herdianti, A., \& Dharmayana, I. W. (2017). Penggunaan media manipulatif untuk meningkatkan aktifitas pembelajaran matematika (PTK di Kelas IV A SD Negeri 1 Kota Bengkulu ), 16(2).

Karyanti, T. (2019). Pendidikan anti korupsi berbasis multimedia. Yogyakarta: Deepublish.

Khairani, M., \& Febrinal, D. (2016). Pengembangan media pembelajaran dalam bentuk macromedia flash materi tabung untuk SMP kelas ix. Jurnal Iptek Terapan, 10(2), 95-102, (Online), (https://doi.org/10.22216/jit.2016.v10i2.422)

Kristanti, D. (2014). Meningkatkan pemahaman melalui media manipulatif. 1(2), $1-16$.

Latuheru, J. (1988). Media pembelajaran dalam proses belajar masa. Jakarta: Depdikbud.

Mayasari, N., P, N. I., Novianti, D. E., Indriani, A., \& Noeruddin, A. (2017). Pemanfaatan media pembelajaran geoboard dalam pembelajaran matematika materi keliling dan luas bangun segi empat dan segitiga. 1(1), 60-65.

Rosmalina, P., Darsono, \& Sulistiasih. (2019). Pengaruh penggunaan media manipulatif terhadap hasil belajar matematika siswa kelas V SD. Jurnal $\begin{array}{lllll}P G S D, & 12(2), & 133-140, & 9,\end{array}$ (https://doi.org/10.33369/pgsd.12.2.133-140).

Suprihatiningrum, J. (2013). Strategi pembelajaran teori dan aplikasi. Yogyakarta: ARRuzz Media.

Susiaty, U. D., \& Oktaviana, D. (2018). Desain aplikasi media pembelajaran untuk membantu pemahaman siswa tentang konsep geometri. SAP (Susunan Artikel Pendidikan), 3(1), 18-26, (https://doi.org/10.30998/sap.v3i1.2731)

Yeni, E. M. (2011). Pemanfaatan Benda-Benda Manipulatif untuk Meningkatkan Pemahaman Konsep Geometri dan Kemampuan Tilikan Ruang Siswa Kelas V Sekolah Dasar. Pemanfaatan Benda-Benda Manipulatif Untuk Meningkatkan Pemahaman Konsep Geometri Dan Kemampuan Tilikan Ruang Siswa Kelas V Sekolah Dasar, (1), 63-75, (Online), (http://jurnal.upi.edu/file/7-Ety_Mukhlesi_Yeni.pdf). 